\title{
Psychological and pedagogical correlates of formation of communicative competence of future psychologists-practitioners
}

\author{
Lada Yakovytska $^{1 *}$, Viktoriia Synyshyna ${ }^{2}$, Eduard Pomytkin $^{3}$, and Olena Khokhlina ${ }^{1}$ \\ ${ }^{1}$ National Aviation University, Department of Aviation Psychology, ave. Sviatoslav Huzar 1,03058 Kyiv, \\ Ukraine \\ ${ }^{2}$ Uzhhorod National University, Department of PsychologyNarodna Square, 3, 88000, Uzhhorod, Ukraine \\ ${ }^{3}$ Ivan Ziazun Institute of Pedagogical and Adult Education of the National Academy of Pedagogical Sciences \\ of Ukraine, Department of Occupational Psychology str. Maxim Berlinsky, 9, Kyiv, Ukraine
}

\begin{abstract}
The article describes the personality characteristics of future psychologists-practitioners, who may at the same time be constituents of their professiogram, among which communicative competence occupies an important place. The purpose of our research was to study the psychological and pedagogical correlates of communicative competence of future psychologists-practitioners through the analysis of its separate components, which are resources for building effective communications. Communicativeness is defined as a professional basic competence that includes the following elements: tolerance, intolerance, acceptance of oneself, acceptance of others, self-regulation of one's own emotions and states, flexibility, contactability, understanding of client's emotions. At the same time, communicativeness is explored as the basic competence of a psychologist-practitioner, which sets the client up for positive and productive interaction in the process of psychological help, which is not an innate skill, so it can be improved during both professional training and during life. The statistical significance of the selected psychological and pedagogical correlates and their psychological components is determined. The multidimensional correlation study showed significant positive and negative correlations between the studied indicators. The components of psychological and pedagogical correlates of communicative competence are analyzed and substantially explained: tolerance, intolerance, flexibility in the communicative process, contactability, communicative control, communicative abilities.
\end{abstract}

\section{Introduction}

The professional training of practical psychologists should be based on a combination of two areas: the formation of professional competence and the development of personal potential. The psychologist's professional competence includes activity-role characteristics (knowledge, abilities and skills) and personality characteristics, which at the same time may be part of future psychologists professiogram, among whom communication competence occupies an important place. Moreover modern scientific and practical psychology a priori

* Corresponding author: lada_yakovickaya@ukr.net 
posits that the development of the personality qualities of psychologists, especially at the stage of their formation as specialists, determines the formation of their professional qualities. That is why it is necessary to recognize and acknowledge the difficulties in communication and interaction with others and in understanding themselves [1] in a timely manner and in the process of professional development of the personality of psychology students.

In the professional activity, the psychologist-practitioner will use not only professional knowledge, which is the core of professional activity, but will also convey it through his own communicative competence. Since the psychologist in a professional activity is focused on the interaction with the client, and it is impossible to distinguish unambiguous algorithms for working with a particular client, the basic qualitative indicator of the psychologist's professionalism is a set of knowledge, skills, erudition, intuition and communication skills. It is imperative, among other things, to be able to devise tools that help to choose a productive and acceptable option for the client to overcome this or that problematic life situation.

The formation and development of communication skills is an element of a competent approach to the professional training of psychologists-practitioners, which is synergistically intertwined with the personal-oriented approach relevant to the educational environment. Competent and personality-centered approaches help to prepare for life and practice activity, and in turn, the communication skills formed within these approaches provide an opportunity to overcome not only life challenges but also to realize in the profession of psychologist.

Scientific analysis of the essence of communicative competence has shown that it is considered by researchers in three dimensions: it is a sphere of issues where the personality has knowledge and experience; the effectiveness and efficiency of the subject's actions is present; the ability of a personality acquired during training that can be used to perform practical and theoretical tasks [2-8].

Related to the above studies are the views of Smith and Wilson (2010), who believe that communicative competence can be considered within a particular situation, in terms of evaluating the outcome of communication [9]. The above scientific positions are close to the research of the American scientist D.Hymes (1971) (who introduced the term "communicative competence") that in the process of implementation of the competency approachthe student acquires knowledge, develops his abilities and skills. Through the notion of "knowledge, skills and ability" D.Hymes (1971) defines communicative competence [10].

Spitzberg and Cupach (1984) have developed their own three-component model of communicative competence, which includes knowledge (understanding which communicative behavior is most appropriate in a particular situation); skills (the ability to use this behavior in a particular context) and motivation (striving for effective and optimal communication) [11].

Despite many approaches to understanding the meaning of the concept of "communicative competence", in general terms, we define it as the ability to convey information, emotions and feelings, perceive information from others, experience empathy, understand the mental states of others and empathize with personalities. Communicativeness as a professional basic competence should include such elements as non-verbal communication, self-regulation of one's own emotions and states, active listening, understanding of the client's emotions. In this regard, communication is the basic competence of the psychologist, which sets the client to a positive and productive interaction in the process of psychological help. According to the research of Kolmogorova (2015), the psychologist's communicative competence implies the following skills: to bring to the partner the content of information in the language available to him, to provide critical information from positive constructive positions, to adhere to the communication of common values, principles and ideals in society, to be attentive, not to diminish the dignity of a communication partner, not to show aggressive intentions, to control the time of communication, to give the partner the opportunity to react to information [4]. 
Solov'eva and Anikeeva (2012) believes that the communicative qualities of a psychologist are the ability to effectively resolve conflicts, free possession of verbal and nonverbal means of communication, logical and clear language, courtesy, tact, sense of humor [7].

The communicative competence of the future psychologist-practitioneris defined as the level of personality experience in communication and the level of professionalexperience of communication, which will lead to career growth and competitiveness of the psychologist, since the psychologist with high degree of stress resistance and skills of effective communication (soft skills)has high personality performance [12]. Girolamo D'Alleo (2011) emphasizes the importance for the psychologist to have high professional, interpersonal and communication skills. The repertoire of skills must be clearly defined; psychology students need to develop a professional "I" in the course of study, which will be structured according to their specialty [13].

It should be emphasized that communicative competence is not an innate skill, it is an acquired skill that can be perfected during both professional training and during life. In this research, we will be guided by the statement that in the process of implementation of the competence approach, knowledge is acquired, abilities and skills are developed, aimed at improving the key (basic), general competences of the personality. The personality-oriented approach, in turn, enables the personality formation, development of the student's personality qualities and abilities, among which the formation of communicative abilities, the ability to make contact is of great importance.a

Given the above, as a diagnostic tool for the study of the components of communicative competence, we have chosen techniques that are highly able to differentiate as states of tolerance - intolerance, adaptation - disadaptation in the system of interpersonal relationships, and individual features of interaction with others.

The purpose of our research is to study the psychological and pedagogical correlates of communicative competence of future psychologists-practitioners through the analysis of its individual components, which are resources for building effective communications.

The hypothesis of our study is the assumption that the communicative competence and peculiarities of the communicative activity of the psychologist-practitioner are objectively determined by the level of development of adaptive potential, willingness and ability to build contacts with people, maturity of internal assisting resources.

\section{Methods}

During the empirical research we studied: the psychological correlates of the communicative competence of future professionals in the assisting professions. Students of the specialty "Psychology" of the National Aviation University of Kyiv and National University of Uzhgorod participated in the study. The sample was 88 people. Conversations and standardized surveys were conducted to find out the personality resources for building effective communications. Based on previous theoretical analysis of recent research, we have formulated psychological and pedagogical resource components of communicative competence and selected methods for their research:

- the ability to effectively interact with people through understanding their own and partner's states, interpersonal relationships, changing communication conditions (the methodic of social and psychological adaptation (SPA), proposed by K.Rogers and R.Diamond; test for emotional intelligence of N.Hall);

- adequate assessment of one's own and partner's potential in the situation of uncertainty (the methodic of determining the individual level of tolerance of S.Badner (in the modification of T.V.Kornilova, M.O.Chumakova)); 
- willingness and ability to build contacts with people (self-actualization test (SAT), scales: flexibility in communication process, contactability; COA questionnaire, offered by B.O.Fedoryshyn);

- internal resources of regulation of communicative actions (diagnostics of rigidity of G.Aizenk; methodic of diagnostics of communicative control by M.Schneider; individual typological questionnaire (ITQ) by L.M.Sobchik);

- internal helping resources necessary for building effective communicative action in a certain range of situations of interpersonal interaction (index of satisfaction with life of N.V.Panina, test of reflection of A.V.Karpov).

Mathematical data processing was performed using the SPSS 17.0 statistical package for Windows.

\section{Results}

The large amount of empirical material collected led to the need to establish the statistical significance of the selected psychological correlates immediately. Statistical data processing was aimed at streamlining the source material, creating a coherent system of data, on the basis of which a further description of the process of formation of communicative competence of psychologists-practitioners is possible. Regarding the ability of statistical criteria to detect differences, we selected non-parametric differences criteria. Practice shows that the vast majority of data obtained in psychological research is not normally distributed, so the use of parametric criteria in the analysis of results can lead to errors in statistical conclusions. Therefore, when estimating differences in distributions that are far from normal, non-parametric criteria can reveal significant differences, while parametric criteria do not reveal such differences.

One of the most common methods used to calculate the presence of a statistical relationship is the theory of correlation research, developed by English mathematician and philosopher Carl Pearson. The strategy of conducting such a study is to determine the controlled effect on the object, but the presence of correlation is not yet evidence of the existence of cause and effect dependencies, but it makes it possible to put forward such a hypothesis. The absence of correlation allows us to refute the hypothesis of a cause and effect relationship between the variables. The measure of statistical dependence between the variables was calculated using the Pearson's correlation coefficient.

A multivariate correlation study to test the hypothesis of a relationship between the above psychological and pedagogical correlates with communicative competence showed that in the created sample of future psychologists-practitioners, there was a significant positive correlation between tolerance and introversion indicators $(\mathrm{r}=0.3 ; \mathrm{p}<0.041)$, tolerance and escapism $(\mathrm{r}=0.36 ; \mathrm{p}<0.038)$. In addition, a negative statistically significant relationship was found with indicators of emotional intelligence level $(\mathrm{r}=-0.37$; $\mathrm{p}<0.029)$, lability $(\mathrm{r}=-0.34$; $\mathrm{p}<0.032)$, acceptance of others $(\mathrm{r}=-0.38 ; \mathrm{p}<0.029)$, flexibility $(\mathrm{r}=-0.37 ; \mathrm{p}<0.029)$, and selfacceptance $(\mathrm{r}=-0.53 ; \mathrm{p}<0.001)$. The results obtained prove that tolerance as a psychoemotional stability in a situation of uncertainty is positively associated with escapism as an adaptation strategy by Kutuzova [14]. Thus, escapism is functionally similar to tolerance, it is a compensatory mechanism that arises because of the decrease in the level of adaptation of the personality to the existing reality. Likewise, the introversion scale is related to seclusion, restraint of personality.

Therefore, negative correlation relationships are obvious, in such circumstances, they are illustrated by scales related to feelings, emotionality, motivational instability, and willingness to change. The negative link to the acceptance of others scale has traditionally been explained by intolerance, but the primary data we have gathered prove the opposite. These data are close to the conclusions of Mirimanova (2001), which proves that there is an external tolerance (attitude towards others) and internal tolerance (the ability to make decisions, 
thoughts about a problem, so it is obvious that the tolerance we have diagnosed is internal willingness to perceive unfamiliar and risky situations as stimulating, willingness to adapt to an uncertain activity or idea [15].

The study mostly involved young people 19-20 years old, who due to age characteristics (youthful maximalism) have a high level of self-acceptance. This indicator is higher than standard for each subject, so the negative relationship with tolerance can be explained by the complexity of the reflective assessment of one's own qualities. Summarizing the results by the indicators of self-acceptance ( $70 \%$ of respondents have average level of self-acceptance, $30 \%$ - high) and others ( $74 \%$ of respondents have average acceptance of others, $26 \%$ - high), we can say that respondents with a great deal of trust in themselves, their own actions, consider their own personality as holistic and unique. Therefore, in the activity and communication, modern youth has less self-restraint, does not always try to live up to the expectations of others, but acts according to their own intentions, so these indicators have an inverse relationship.

One of the authors of the methodology, K. Rogers [16], considered "acceptance of others" as affectionate and respectful attitude to the communication partner, regardless of his state, behavior or feelings. The "other" has unconditional value, the whole spectrum of his relations at the moment is accepted and respected. Therefore, this index, by analogy with indicators of emotional intelligence, has an inverse relationship with tolerance. Thus, the more sensitive a person is, the more difficult it is to show tolerance, even with a sufficient level of readiness for uncertain situations. We consider tolerance as a constructive correlate of communicative competence that creates readiness of a psychologist-practitioner for a variety of unexpected situations characterized by a variety of possible solutions.

Statistically significant positive relationships according to the methodic of S.Badner (in the modification of T.V.Kornilova, M.O.Chumakova) were revealed between the scales of tolerance, intolerance and interpersonal intolerance (Table 1).

Thus, in our study, the fact described in the works of Khilko [17] verified that a high level of positive attitude to the situation of uncertainty does not exclude the formation of intolerance (striving for clarity regarding experience and people) in future psychologistspractitioners. Such an explanation of the correlation relationship is possible due to the research of Kornilova and Chumakova [18]. In their modification of the methodic, it is possible to measure tolerance and intolerance to uncertainty as two variables rather than two poles on the same scale. That is, there are reasons to consider tolerance and intolerance as independent psychological entities associated with different properties in the integral professional and personality potential of a person.

Table 1. Correlation relationship between tolerance-intolerance scales.

\begin{tabular}{|l|c|c|c|}
\hline $\begin{array}{c}\text { Scales of tolerance and } \\
\text { intolerance to uncertainty in } \\
\text { the modification of } \\
\text { S.Badner's questionnaire }\end{array}$ & $\begin{array}{c}\text { Tolerance as } \\
\text { psycho- } \\
\text { emotional } \\
\text { stability }\end{array}$ & $\begin{array}{c}\text { Intolerance } \\
\text { (striving for } \\
\text { clarity) }\end{array}$ & $\begin{array}{c}\text { Interpersonal } \\
\text { intolerance } \\
\text { (striving for } \\
\text { clarity in } \\
\text { relationships) }\end{array}$ \\
\hline $\begin{array}{l}\text { Tolerance as psycho-emotional } \\
\text { stability }\end{array}$ & 1 & $\begin{array}{c}0,41 \\
\mathrm{p}=0,017\end{array}$ & $\begin{array}{c}0,37 \\
\mathrm{p}=0,030\end{array}$ \\
\hline Intolerance (striving for clarity) & 0,41 & 1 & 0,46 \\
$\mathrm{p}=0,017$ & 0,37 & 0,46 & 1 \\
\hline $\begin{array}{l}\text { Interpersonal intolerance } \\
\text { (striving for clarity in } \\
\text { relationships) }\end{array}$ & $\mathrm{p}=0,030$ & $\mathrm{p}=0,006$ & \\
\hline
\end{tabular}

Further correlation analysis of intolerance scales to the uncertainty revealed that the intolerance scale (striving for clarity) had a positive significant relationship with emotional awareness indicators $(\mathrm{r}=0.32 ; \mathrm{p}<0.05)$, ability to manage emotions $(\mathrm{r}=0.34) ; \mathrm{p}<0.047)$, selfmotivation $(\mathrm{r}=0.29 ; \mathrm{p}<0.05)$. These indicators help the person to feel more confident about 
an uncertain situation, and self-motivation further pushes them forward. A negative significant relationship was established for the anxiety index $(r=0.36 ; p<0.038)$. It is quite obvious. A high degree of anxiety can significantly affect the determination to move forward. Interpersonal intolerance (striving for clarity in relationships) in our study has only inverse relationship on lability indicators $(\mathrm{r}=-0.32 ; \mathrm{p}<0.05)$, reflectivity $(\mathrm{r}=-0.33 ; \mathrm{p}<0.05)$ and communicative control $(\mathrm{r}=-0.34 ; \mathrm{p}<0.047)$. These relationships are obvious, the better the specialist analyzes complex or unexpected situations, controls their impulses, the more it makes the relationship predictable and transparent.

As mentioned above, communicative control allows us to constructively regulate interpersonal relationships and the flow of professional, socially significant situations, as well as its indicators have a positive significant relationship with indicators of self-acceptance $(r=0.36 ; p<0.037)$, ability to recognize emotions $(r=0.27 ; p<0.05)$, lability $(r=0.27 ; p<0.05)$ and flexibility $(\mathrm{r}=0.34 ; \mathrm{p}<0.048)$. That is, communicative control allows the psychologist to produce similar patterns of thinking and behavior about the expectations of others. This personality trait not only determines the thinking and behavior of the specialist, but is also the result of creating and maintaining the relevant content field by communicative methods. Ability to recognize emotions, flexibility, lability ( $24 \%$ of respondents showed a normal level of expression and $76 \%$ moderate) as a desire for emotional involvement, easy entry into any social roles, imitation in behavior ensure the course of self-regulation in uncertain situational conditions of communication. Moreover, accepting oneselfwith their characteristics, without negative coloring, facilitates the course of self-regulation and internal control.

Analysis of the psychological components of personality flexibility in the communication process showed a significant positive correlation between the indicators of flexibility and emotional awareness $(\mathrm{r}=0.36 ; \mathrm{p}<0.036)$, the ability to recognize emotions $(\mathrm{r}=0.47 ; \mathrm{p}<0.005)$, empathy $(\mathrm{r}=0.35 ; \mathrm{p}<0.041)$, life satisfaction $(\mathrm{r}=0.44 ; \mathrm{p}<0.01)$. Thus, flexibility provides a positive relationships with others, the ability to find a compromise in difficult situations. According to many scientists, positive relationships with others are an important component of psychological well-being and life satisfaction. Thus, the positive results of interpersonal interaction, as indicators of communicative competence, are provided with such skills as emotional awareness, the ability to recognize emotions, empathize, they help to establish and maintain contacts with other people.

The next component of communicative competence that was considered in the course of the study is contactability. Contactability by Maslou is understood not as a level of communicative ability of a person or as a skill for effective communication, but as a general tendency to mutually beneficial and enjoyable contact with other people [19]. The contactability scale in the self-actualization questionnaire measures a person's ability to make deep and close contact with others. A sign of communicative competence and the level of professional psychologist is the ability to easily and quickly make contact, and such relationships do not seem superficial. Significant positive correlation for contactability was established with indicators of emotional awareness $(\mathrm{r}=0.4 ; \mathrm{p}<0.018)$, ability to recognize emotions $(r=0.33 ; \mathrm{p}<0.05)$, spontaneity $(\mathrm{r}=0.33)$; $\mathrm{p}<0.05)$.

We see that, for contactability and flexibility, common correlates of emotional awareness, the ability to recognize emotions, are highlighted. A distinctive correlate of spontaneity is a property that is reflected in the high search activity of a specialist, assertiveness and strong self-presentation of own "I". This property really increases the probability of making contact with a stranger, so it is valuable for the psychologist-practitioner who works with clients and has to overcome self-doubt and far-fetched fears about the therapy situation itself. The survey showed that the majority of respondents had moderate or normal levels of spontaneity $(47 \%$ and $44 \%$ respectively).

The last component and correlates of it that we analyzed was the communicative ability of future psychologists. A significant positive correlation was found with emotional awareness $(r=0.37 ; \mathrm{p}<0.032)$, which has a clear relationship with a person's communicative abilities through understanding own experiences and experiences of others, being able to 
control and adequately identify emotions, and escapism $(\mathrm{r}=0.42 ; \mathrm{p}<0.014)$. Escapism in our study is a compensatory, adaptive mechanism that allowsto realize a specialist's own abilities, including communicative ones. A negative correlation with spontaneity was found $(\mathrm{r}=-0.35$; $\mathrm{p}<0.042$ ). This connection can be explained by the different content of spontaneous actions. For example, if spontaneity manifests itself in the background of underestimation of other participants in the interaction, it can really reduce the specialist's ability to communicate productively. Or it occurs in hyperres ponsive situations of increasing internal tension, against the background of the desire to better control the same situation, at the same time will increase and anxiety due to the smallest manifestation of spontaneity, respectively, in the obtained statistical results we have a high positive relationship of these correlates $(\mathrm{r}=0.45$; $\mathrm{p}<0.008$ ). In such cases, it is difficult to strike a certain balance between communicative control and spontaneous behavior. It is the interaction of these two processes that will reduce the communicative ability and, accordingly, the communicative competence of the specialist.

According to the research of specialists, the achievement of "controlled spontaneity" may be the optimal condition under such conditions.

\section{Discussion}

Having analyzed the assets of foreign and domestic psychologists on the issues of diagnostics, formation and development of communicative competence of psychology students [5, 20-24], we can state that it is possible to develop communication abilities and skills in terms of higher education institution using personality-oriented educational technologies, which include reflexive, dialogical, interactive teaching methods. Among them, the case method, simulation of the situation, problem tasks solving, the Socratic conversation, role-playing gamesplay occupy an important place.

Our analysis of scientific approaches to the essence of communicative competence in different professional fields [25-27] allowed us to determine the conditions and factors that are necessary for productive communicative activities of future psychologists-practitioners. As we can see, most scholars are of the opinion that for basic communicative competence it is necessary to combine communicative knowledge (mastering the theory of professional communication) and skills (entering into technology of the process in practice), forming as a result of this professional and communicative experience, of both students and teachers [27$31]$.

In our opinion, in order to study the essence and formation of the communicative competence of the personality of the psychologist-practitioner it is necessary to study the socio-psychological adaptation and related to it personality traits, communicative flexibility, ability to establish close contacts with the environment, emotional stability, readiness for change, since we believe that communicative competence is determined not only by the theoretical, practical readiness of future psychologists-practitioners, but also by the psychological components through which the genesis of personality happens, as during professional training students undergo several stages of development, namely: adaptation, intensification, identification [32]. In the process of passing these stages, the establishment of interpersonal relationships with each other occurs. Of particular importance at this stage are the individual and psychological characteristics of the personality, emotional stability, personal self-determination and identification of one's own lifestyle and professional selfrealization.

Constructive passage of stages is determined by such indicators as positive selfperception, acceptance of others, emotional comfort, flexibility of thinking, developed emotional intelligence, adequate level of self-esteem, the presence of adequate selfevaluation, independence of judgments. Coherence of the structural components of the "Iconcept", a positive attitude towards your self as a personality and a specialist is an important 
prerequisite for acquiring basic competencies, among which communication competence is crucial.

\section{Conclusions}

In the process of acquiring communicative competence, specific professionally important qualities of personality are formed, which is a necessary condition for successful selfrealization in the labor market. In such circumstances, it is adaptable to the requirements of the profession that are related to: the inclusion of a new search engine in the overall rhythm of activity; reconciling their difficult expectations with the demands of other players; establishment of the necessary psychological contact and mutual understanding; the development of a new labor standard of personality, which is due to its entry into the field of support activities; assimilation of norms and values of activity and professional group engaged in it; and also with the overcoming the contradictions between expectations of personality, its professional ideas, from one side, and the nature of real requirements, specific work skills, daily interaction practices, from the other side.

Communicative competence in work is regarded as a system of internal resources necessary to build effective communication in the range of professional situations of interpersonal interaction by psychologists-practitioners.

Analysis of the components of psychological and pedagogical correlates of communicative competence, such as tolerance, intolerance, flexibility in the communicative process, contactability, communicative control, communicative abilities, showed that tolerance, as a constructive correlate of communicative competence, is positively associated with escapism as an adaptation strategy and introvertivity of personality. The scale of intolerance (striving for clarity) has a positive significant relationship with the indicators of emotional awareness, ability to manage emotions, self-motivation. Interpersonal intolerance (strivingfor clarity in relationships) in our study has only inverse relationship on indicators of lability, reflectiveness, and communicative control. Communicative control has relationship with such personality traits as acceptance of oneself, ability to recognize emotions, lability and flexibility. Flexibility and contactability of the personality in the process of communication are mainly determined by emotional awareness, ability to recognize emotions, empathy, life satisfaction. Communication skills are positively correlated with emotional awareness and escapism, as an adaptation mechanism that allows one to realize a specialist's own abilities, including communicative ones.

As a prospect of the research we see the approbation of training exercises aimed at developing communicative competence in the subject-subject relations of the assisting profession of psychologist, that will absorb the "transformed actual forms" of socio-cultural and professional requirements for the modern psychologist-practitioner.

\section{References}

1. L.S. Yakovytska, Naukovyi visnyk Khersonskoho derzhavnoho universytetu. Seriia "Psykholohichni nauky" 6 (1), 159-163 (2016).

2. A.A. Berger, Media and Communication Research Methods: An Introduction to Qualitative and Quantitative Approaches (San Francisco State University, USA, 2014).

3. S. Littlejohn, A. Karen, Foss Encyclopedia of Communication Theory (Thousand Oaks, California, 2009).

4. L.A. Kolmogorova, Formirovaniye kommunikativnoy kompetentnosti lichnosti (AltGPU, Barnaul, 2015).

5. O.M. Korniiaka, Psykholinhvistyka 7, 31-40. (2010).

6. M. Lustig, J. Coester, Intercultural Communication: Interpersonal Communication Across Cultures (Pearson Education, Boston, 2010).

7. O. V.Solov'eva, Yu. V. Anikeeva, Vektor nauki TGU, 1 (8), 267-269 (2012). 
8. I.O. Cherezova, Naukovyi visnyk Khersonskoho derzhavnoho universytetu. Seriia "Psykholohichni nauky", 1 (1), 103-107 (2014).

9. S. Wilson, Explicating Communicative Competence as a Theoretical Term. Handbook of Communication and Social Interaction Skills (Erlbaum, Mahwah, N. J., 2003).

10. D.H. Hymes, Language acquisition: Models and methods, 3-28 (Academic Press, New York, 1971).

11. B.H. Spitzberg, W.R. Cupach, Interpersonal communication competence (BeverlyHills, CA, 1984).

12. L.S. Yakovytska, Aktualni problemy psykholohii 2 (XIV), 443-452 (2019).

13. G. D'Alleo, Procedia - Social and Behavioral Sciences 15, 3674-3682 (2011).

14. D.A. Kutuzova, Proceedings of the Conference "Lomonosov-2001". Available on http://content.mail.ru/ arch/18140/1318773.html.

15. M.S. Mirimanova, Razvitie issledovatelskoy deyatelnosti uchashchikhsya, 99-115 (Narodnoe obrazovanie, Moscow, 2001).

16. E.V. Sidorenko, Metody matematicheskoy obrabotki v psikhologii (Sbp“Rech", Saint-Petersburg, 2000).

17. S.O. Khilko, Problemy suchasnoi psykholohii 38, 421-437 (2017).

18. T.V. Kornilova, M.A. Chumakova, Eksperimentalnaya psikhologiya 7 (1), 92-11. (2014).

19. A.G. Maslou, Motivatsiya i lichnost' (Yevraziya, Saint-Petersburg, 1999).

20. N.B. Zavinychenko, Osoblyvosti rozvytku komunikatyvnoi kompetentnosti maibutnoho praktychnoho psykholoha systemy osvity (Instytut psykholohii im. H. S. Kostiuka APN Ukrainy, Kyiv, 2003).

21. N.P. Serhiienko, O.Yu. Chuiko, Problemy ekstremalnoi ta kryzovoi psykholohii 22, 284-290 (2017).

22. V.M. Synyshyna, Proceedings of the All-Ukrainian Scientific-Practical Internet Conference "Domestic Science at the Turn of the Ages: Problems and Prospects for Development" 48, 125127. (2019).

23. N.V. Chepelieva, Psykholohiia III, 35-41 (1998).

24. L.O. Khomych, L. M. Urapa, Psykholohiia II, 109-112 (1998).

25. S. Baker, B. Watson, \& C. Gallois, Intercultural communication, 481-499 (De Gruyter Mouton, Berlin, 2017).

26. J.O. Greene, Verbal Communication, Book Series: Handbooks of Communication Science, 3, 549-565 (2016).

27. M. Romero-Martin, F.-J. Castejon-Oliva, V.-M. Lopez-Pastor, A. Fraile-Aranda, Comunicar 25 (52), 73-82 (2017).

28. A. Arroyo-Sagasta, Revista Mediterránea de Comunicación 8 (2), 277-285 (2017).

29. J. L. Gallego Ortega, \& A. R. Fuentes, Movimento 20 (2), 425-444 (2014).

30. B. Klebig, J. Goldonowicz, E. Mendes, A. N. Miller, J. Katt, Communication Research Report 33 (2), 152-158 (2016).

31. L.S. Yakovytska, Psykholohiia: teoriia i praktyka 2(2), 181-190 (2018).

32. T.O. Koren, Teoriya i praktyka suchasnoyi psykholohiyi 1, 73-76 (2010). 